\title{
REFRAÇÃO SÍSMICA PROFUNDA NO SETOR SUDESTE DA PROVÍNCIA TOCANTINS
}

\author{
Fábio André Perosi \\ Orientador: Dr. Jesus Antonio Berrocal Gomez (IAG-USP) \\ 115 p. - Dissertação (Mestrado) \\ Defesa: $31 / 7 / 2000$
}

\section{RESUMO}

0 presente trabalho está inserido nos estudos de refraçãa profunda do Projeto Temático "Estudos Geofísicos e Modelo Tectônico dos Setores Central e Sudeste da Província Tocantins". Nesses estudos foram levantadas três linhas de refração de aproximadamente 300km de extensão, duas no setor Central da Província Tocantins e uma no setor Sudeste, que é o objeto de estudo deste resumo. Foram utilizados 111 sismógrafos digitais SGR pertencentes ao programa PASSCAL, instrumentos auxiliares do USGS, e 13 sismógrafos digitais e instrumentos auxiliares do IAG/USP. A linha sísmica teve aproximadamente $300 \mathrm{~km}$ de extensão, com pontos de registro separados a cada 2,5 km, distribuídos ao longo de estradas principais e secundárias. A cada $50 \mathrm{~km}$, aproximadamente, foi realizada uma explosão, nas explosões dos extremos da linha foram utilizados $1000 \mathrm{~kg}$ de explosivo e para a explosão central uma carga de $500 \mathrm{~kg}$. Para a determinação das coordenadas geográficas dos pontos de tiro e de registro, foi utilizado o método diferencial com medidas de GPS. 0 principal objetivo foi obter como produto final um modelo de velocidades sísmicas contendo as características físicas das principais descontinuidades na crosta terrestre e no manto superior. Para análise e processamento dos dados foram utilizados os pacotes SAC, SU, SEIS. Para o modelamento foram utilizados a teoria do raio e a elaboração de sismogramas sintéticos, do pacote SEIS. Para a elaboração do modelo final foram utilizados os dados das explosões dos pontos extremos e centrais, tendo em vista que devido a problemas técnicos não foram registrados os sinais das outras quatro explosões. Além disso, as explosões registradas não apresentaram sinais claros em toda a extensão da linha. Devido a isso e considerando as unidades geológicas presentes na região de estudo, são sugeridos três modelos de velocidades sísmicas. 0 primeiro modelo refere-se ao tiro direto (EX31), localizado no extremo sudoeste da linha, sobre a Bacia do Paraná. Para este modelo obteve-se para superfície $(0 \mathrm{~km})$ a velocidade inicial de $2 \mathrm{~km} / \mathrm{s}$ (coberturas); para a profundidade de $0,086 \mathrm{~km}$ a velocidade inicial é de $5,15 \mathrm{~km} /$ $s$ (basalto); para a profundidade de $0,350 \mathrm{~km}$ obteve-se a velocidade inicial de $4,6 \mathrm{~km} / \mathrm{s}$ (arenito-camada de baixa velocidade); para a profundidade de $0,650 \mathrm{~km}$ a velocidade inicial é de $5,75 \mathrm{~km} / \mathrm{s}$ e para a profundidade de $4 \mathrm{~km}$ obteve-se a velocidade inicial de $6,07 \mathrm{~km} / \mathrm{s}$. 0 segundo modelo refere-se ao tiro reverso (EX34), localizado no centro da linha sobre granitóides do Grupo Araxá. Para este modelo obteve-se para superfície (0 km) a velocidade inicial de $2 \mathrm{~km} / \mathrm{s}$; para a profundidade de $0,06 \mathrm{~km}$ a velocidade inicial de $5,69 \mathrm{~km} / \mathrm{s}$ e para a profundidade de 0,860 $\mathrm{km}$ obteve-se a velocidade inicial de 6,25 km/s. Finalmente, 0 terceiro modelo refere-se ao tiro direto para toda a extensão da linha $(300 \mathrm{~km})$. Este modelo foi definido a partir de fases secundárias lidas nos registros e modelos anteriores propostos na literatura. Da superfície até os $4 \mathrm{~km}$ iniciais de profundidade este modelo é igual ao primeiro, para uma profundidade de $20 \mathrm{~km}$ obteve-se a velocidade inicial de $6,70 \mathrm{~km} / \mathrm{s}$ e para uma profundidade de $40 \mathrm{~km}$ a velocidade é de $8,00 \mathrm{~km} / \mathrm{s}$ (descontinuidade de $\mathrm{MOHO}$ ).

\section{ABSTRACT}

This work to fulfil the degree of Master of Sciences is inserted among the deep seismic refraction studies of the Thematic Project "Geophysical Studies and Tectonic Model of the Tocantins Province Central and Southeast Sectors, Central Brazil". Three refraction lines, of around $300 \mathrm{~km}$ long each, were deployed, two of them in the Central sector and the other in the SE sector, that is subject of the present work. The equipment used in this experiment was composed by 111 SGR digital seismographs belonging to the PASSCAL Program. Complemented with auxiliary instruments from USGS and 13 seismographs belonging to IAG/USP. The space among the recording points was $2.5 \mathrm{~km}$, which were located along main and secondary roads. Every $50 \mathrm{~km}$ was fired an explosion with $1000 \mathrm{~kg}$ of emulsion in each extreme and $500 \mathrm{~kg}$ in the central point. The geographical co-ordinates 
were determined by using the GPS differential method. The main objective of this work is to obtain as a final product a seismic velocity model with the physical characteristics of the main discontinuities in the crust and upper mantle. The packages SAC, SU and SEIS were used to perform the data analysis and processing. To carry on the modelling were used the ray theory and the synthetic seismograms construction, belonging to the SEIS package. Data from the extreme and middle points of the seismic line were used to elaborate the final model, considering that due to technical problems signals from the other four explosions were not recorded. Apart from that, the recorded explosions did not present clear signals all along the extension of the line. Due to these facts, and considering also the geological units present in the studied region, are suggested three seismic velocity models. The first model is referred to the direct shot (EX31), which is localised in the Southwest extreme of the line on the Parana Basin province. In this model we obtained the $P$ wave velocity (Vp) of $2 \mathrm{~km} / \mathrm{sec}$ at the surface, corresponding to the unconsolidated sediments and soil on the top of that basin. At a depth of $86 \mathrm{~m}$ we found $V_{p}$ of $5,15 \mathrm{~km} / \mathrm{sec}$ and at a depth of $350 \mathrm{~m}$ the velocity $V_{p}$ of $4,6 \mathrm{~km} / \mathrm{sec}$, corresponding to the basalt and sand layers of the Parana Basin. Underlying them, at $650 \mathrm{~m}$ of depth we found the basement with $V p$ of $5,75 \mathrm{~km} / \mathrm{sec}$ and finally at a depth of $4 \mathrm{~km}$ there is a layer with $V p$ of $6,07 \mathrm{~km} / \mathrm{sec}$, corresponding to a typical upper crust $P$ wave velocity. The second model corresponds to the reverse shot (EX34) that is localised in the middle point of the line on the granitoides of the Araxa Group. For this model we obtained Vp of $2 \mathrm{~km} / \mathrm{sec}$ for the superficial layers, then at a depth of $60 \mathrm{~m}$ was obtained $V p$ of $5,69 \mathrm{~km} / \mathrm{sec}$ and for a depth of $860 \mathrm{~m}$ the value of $V p$ is $6,25 \mathrm{~km} / \mathrm{sec}$. Finally, the third model belongs to the whole line section $(300 \mathrm{~km})$ from the direct shot (EX31). This model was obtained by using the arrivals of secondary phases and the results of models proposed in other works. From the surface down to $4 \mathrm{~km}$ of depth this model is similar to the first one. At $20 \mathrm{~km}$ of depth there is a layer with $V p$ of $6,70 \mathrm{~km} / \mathrm{sec}$, corresponding to the lower crust, with Moho at a depth of $40 \mathrm{~km}$ with $\mathrm{Vp}$ of $8,00 \mathrm{~km} / \mathrm{sec}$. 